\title{
HBM wt Allele
}

National Cancer Institute

\section{Source}

National Cancer Institute. HBM wt Allele. NCI Thesaurus. Code C84968.

Human HBM wt allele is located in the vicinity of $16 \mathrm{p} 13.3$ and is approximately $1 \mathrm{~kb}$ in length. This allele, which encodes hemoglobin subunit mu protein, may play a role in the transport of oxygen to tissues of the body. 